\title{
Taxonomic re-evaluation of Schoenoplectiella lateriflora subsp. laevinux (Cyperaceae) and a new record for Schoenoplectiella erecta subsp. erecta
}

\author{
Martin Xanthos ${ }^{1}$ \& Jane Browning ${ }^{1}$
}

Summary. Micro-morphological examination of nutlets show that Schoenoplectiella lateriflora subsp. laevinux (Cyperaceae), recorded from Tanzania, is synonymous with Schoenoplectiella erecta subsp. erecta, thus extending the range of this species. Examination of herbarium specimens also shows this species to be present in Zambia.

Key Words. Nutlets, SEM, Tanzania, taxonomy, Zambia.

\section{Introduction}

Schoenoplectus section Supini was created by Raynal (1976) to encompass annual species of Schoenoplectus exhibiting amphicarpy. These species were then transferred to Schoenoplectiella Lye (Lye 2003). Schoenoplectiella species, most of which are African, have previously been distinguished on quantitative characters, few of which, unless considered collectively and selectively, are of taxonomic value. Two closely affiliated taxa with distributions extending to other continents are Schoenoplectiella erecta (Poir.) Lye and Schoenoplectiella lateriflora (J. F. Gmel.) Lye. Separation of these two species is based mainly on the number of style branches and nutlet conformation. Subspecies have also been recognised in recent accounts of both of these species. The typical subspecies of $S$. erecta has two style branches and faint transverse waves on the nutlet which scarcely extend over its angles giving the nutlet an almost smooth appearance. Its counterpart in $S$. lateriflora has three style branches and a markedly rugose trigonous nutlet (Table 1).

Schoenoplectus lateriflorus subsp. laevinux Lye was based on a single collection (Wingfield 2036) from just north of Dar es Saalam, Tanzania (Lye 1983). Lye separated it on the basis of its two style branches and flattened slightly transversely wrinkled nutlet. Conversely, pencil annotations on the label indicated that it was a 'form' of Schoenoplectus erectus on the basis of the nutlet sculpturing.

In Africa, Schoenoplectiella erecta subsp. erecta occurs only in the north and west of the continent, but during examination of Kew collections, the second author identified two sheets (Robinson 5448) collected in Zambia purporting to be $S$. erecta subsp. erecta. The first sheet was a mixed collection with two plants sharing the label Scirpus lateriflorus Gmel., (S. lateriflora (J. F. Gmel.) Lye) identified by Schuyler in 1972, and the third plant, also identified by Schulyer, as Scirpus uninodis (Del.)
Coss. \& Dur. (S. erecta subsp. erecta). The second sheet had all its plants determined as Schoenoplectus erectus.

In this paper we: 1) re-assess the taxonomic status of Schoenoplectus lateriflora subsp. laevinux from Tanzania and 2) establish the presence of $S$. erecta subsp. erecta in Zambia.

\section{Materials and methods}

To confirm the identity of Robinson 5448 as that of Schoenoplectiella erecta subsp. erecta, mature nutlets were first observed using a light microscope and images were taken using a digital camera placed against the eyepiece. Comparisons were made with accurately named specimens of the same taxon.

For scanning electron microscopy (SEM) observation, nutlets were directly mounted onto aluminium stubs and sputter coated with platinum for 1 minute. Observations were conducted using an electron microscope with a voltage of $2 \mathrm{kV}$.

In re-evaluating Schoenoplectiella lateriflora subsp. laevinux, nutlets from the isotype at $\mathrm{K}$ were examined under SEM and compared with those from Robinson 5448.

\section{Results and Discussion}

There are few collections at $\mathrm{K}$ of Schoenoplectiella erecta subsp. erecta from Sub-Saharan Africa. Morphometric analysis cannot be reliably carried out until more collections come to light. Of the collections from Senegal, Mali and N Nigeria cited by Hooper (1972), all had two style branches and aerial nutlets, but only de Wailly 5006, a collection from Mali, had a mature aerial and basal nutlet. Nutlet size of Robinson $5448(1.4 \times 1.25 \mathrm{~mm})$ and de Wailly $5006(1.5 \times 1.25 \mathrm{~mm})$ agreed closely, while sculpturing indicated little difference (Fig. 1A - C). The basal nutlet of de Wailly 5006, including the beak, was $2.1 \mathrm{~mm}$ long.

Accepted for publication 14 July 2015. Published online 17 September 2015

1 Herbarium, Royal Botanic Gardens, Kew, Richmond, Surrey, TW9 3AB, UK. e-mail: m.xanthos@kew.org 
Table 1. Morphological comparison of key characters in the subspecies of Schoenoplectiella erecta and S. lateriflora.

\begin{tabular}{lllll}
\hline \hline character & \multicolumn{1}{c}{$\begin{array}{c}\text { S. erecta } \\
\text { subsp. } \text { erecta }\end{array}$} & $\begin{array}{c}\text { S. erecta } \\
\text { subsp. raynalii }\end{array}$ & $\begin{array}{c}\text { S. lateriflora } \\
\text { subsp. lateriflora }\end{array}$ & $\begin{array}{c}\text { S. lateriflora } \\
\text { subsp. laevinux }\end{array}$ \\
\hline stigma branches & 2 & 2 & 3 & 2 \\
nutlet ornamentation & undulate & rugose & rugose & undulate \\
nutlet shape & biconvex & biconvex & biconvex \\
\hline
\end{tabular}

When comparing these dimensions to those of Wingfield 2036, there was also agreement although Lye (1983) gave measurements slightly smaller, namely $1.3 \times$ $1.1-1.2 \mathrm{~mm}$, for the aerial nutlet. Lye also noted that the subspecies differed from Schoenoplectiella erecta subsp. erecta by having only $2 \mathrm{~mm}$ long basal nutlets and shorter glumes. It is our opinion that neither of these statements is sufficient to warrant it subspecies level and combined with aerial nutlet similarity and the presence of two style branches, S. lateriflora subsp. laevinux should be placed in synonymy under $S$. erecta subsp. erecta.
Robinson 5448 is also the first and, at present, only record of Schoenoplectiella erecta subsp. erecta from Zambia. The collection was from an area where rice is an important cash crop so it is possible that this sedge was brought in with rice seeds.

This account extends the known African distribution of Schoenoplectiella erecta subsp. erecta from Madagascar and associated islands, North \& West Africa to Tanzania and Zambia. It is also possible that it has been introduced into several other African countries. The taxon is also present in Australia where it is noted as an introduction.

\section{Key to the subspecies of Schoenoplectiella erecta $\mathcal{E} S$. lateriflora in Africa}

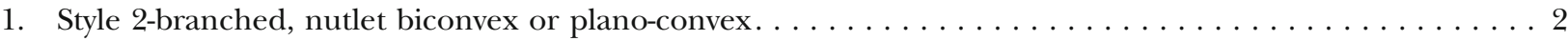

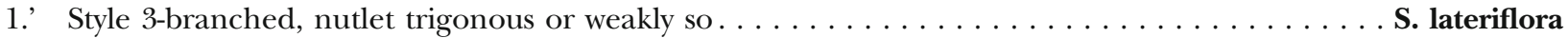

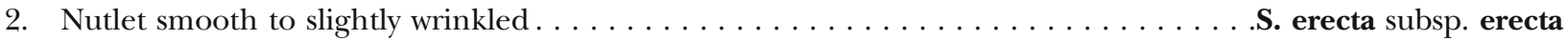

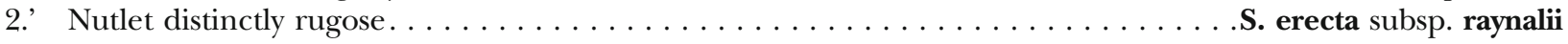

\section{Taxonomic treatment}

Schoenoplectiella erecta (Poir.) Lye (2003: 25); Beentje (2010: 34). Type: Mauritius, du Petit Thouars 13 (holotype P).

Annual, or short-lived tufted perennial, $5-30 \mathrm{~cm}$ (including inflorescence bract). Leaves absent, or less often present, basal sheaths ending in short subulate lobe; may enclose basal 3-styled female florets, developing basal nutlets $\pm 2.2 \times 1.4 \mathrm{~mm}$ long and wide, sometimes with 2 bristles. Inflorescence pseudolateral, overtopped by lower bract, upper bract absent or present, short. Spikelets clustered, subsessile or stalked; reddish-brown to cream, ovoid, $3-18 \times 2-3 \mathrm{~mm}$. Glumes (2.5) 3 - $4 \mathrm{~mm}$ long, triangular, lanceolate, glabrous, margin ciliate or not, mucronate. Perianth bristles absent. Stamens 3, style 2-branched. Aerial nutlet; dark brown to black, lenticular, ovoid, $1.4-1.6 \times 1.1-$ $1.4 \mathrm{~mm}$, smooth to faintly rugose or distinctly rugose.

\section{Schoenoplectiella erecta subsp. erecta}

Schoenoplectiella lateriflora subsp. laevinux Lye (1983: 242), synon. nov. Type: Tanzania, $28 \mathrm{~km}$ straight NNW of Dar es Salaam, $200 \mathrm{~m} \mathrm{~S}$ of Log Cabins, sea level, 15 July 1972, R. Wingfield 2036 (holotype DSM; isotypes EA, K!). (Fig. 2)
DISTRIBUTION. South-Western Europe: Western Portugal \& South-West Spain, Africa: Algeria, Egypt, Libya, Mali, Niger, Nigeria, Senegal, Tanzania, Zambia \& Zanzibar. Madagascar \& Mauritius. India, Vietnam. Possibly introduced in Australia.

SPECIMENS EXAMINED. SENEGAL. 1958, Naegelè s.n. (K!). MALI. Bordue de Marigot, 29 March 1936, de Wailly 5006 (K!). NIGER. Lac Tchad, delta de la rivière Yobè, 19 Feb. 1968, J. Léonard 4536 (K!). NIGERIA. Bornu Province, Chad Distr., 22 March 1963, Jackson 2574 (K!). TANZANIA. $28 \mathrm{~km}$ straight NNW of Dar es Salaam, $220 \mathrm{~m} \mathrm{~S}$ of Log Cabins, 15 July 1972, R. Wingfield 2036 (K!). ZAMBIA. Kalabo, 2 Aug. 1962, Robinson 5448 (K!).

HABITAT. Growing in swampy ground along the edges of water bodies; alt. $1000-1100 \mathrm{~m}$.

CONSERVATION STATUS. Least Concern (LC) due to its wide distribution.

NOTES. This species is distinguished from Schoenoplectiella erecta subsp. raynalii by its smooth to scarcely wrinkled nutlet. The degree of rugosity may be more pronounced in specimens examined from Madagascar and Mauritius and a full global treatment of the two subspecies may be required to establish the delimitation of this character. 


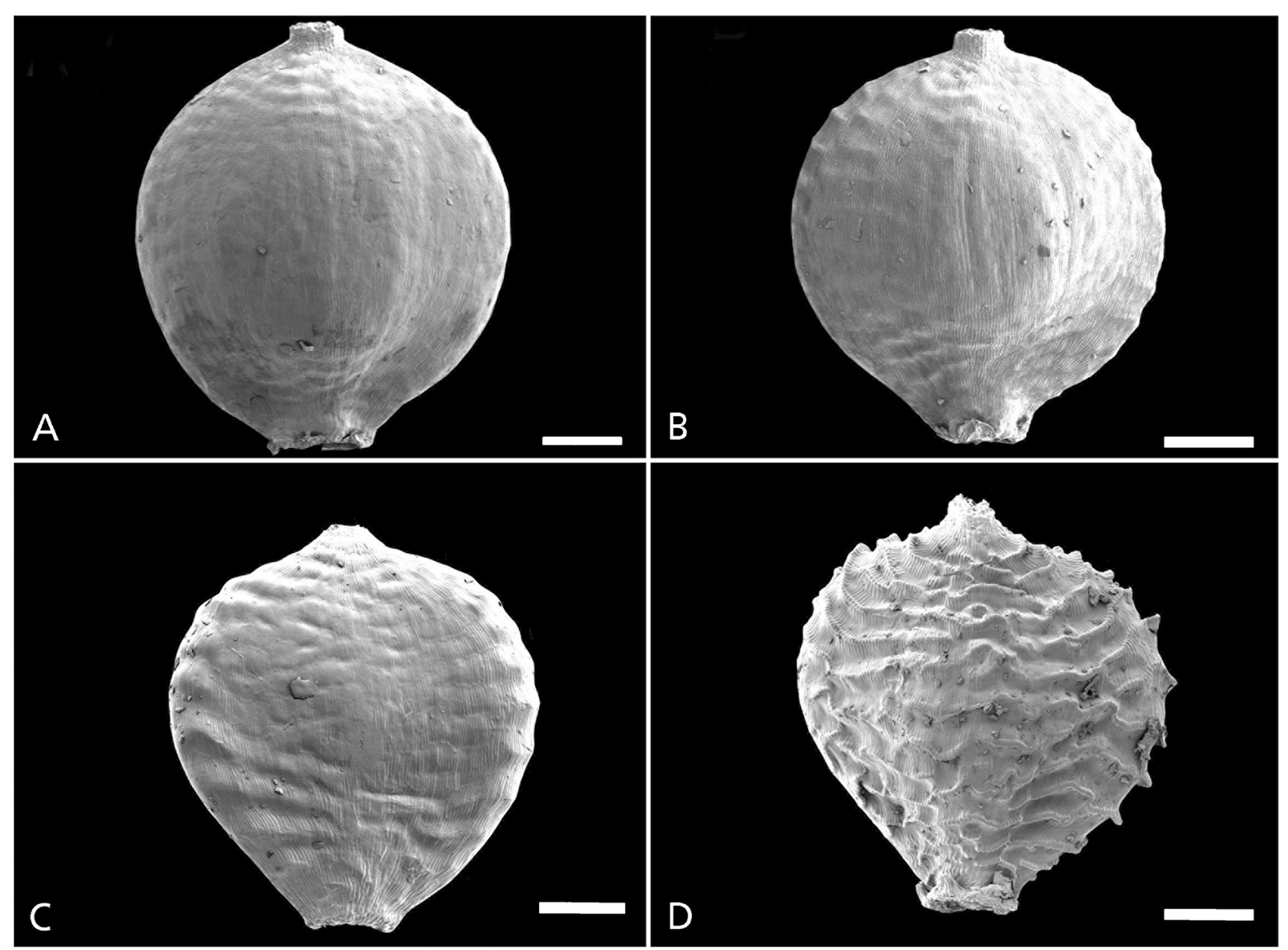

Fig. 1. Scanning Electron micrographs of nutlets. A - C Schoenoplectiella erecta subsp. erecta; D Schoenoplectiella erecta subsp. raynalii. A de Wailly 5006 (Mali); B Robinson 5448 (Zambia); C Wingfield 2036 (Tanzania); D M. G. Bingham \& M. A. Vestergaard 13096 (Zambia). Scale bars $=250 \mu \mathrm{m}$.

Schoenoplectiella erecta subsp. raynalii (Schuyler) Beentje (2010: 34). Type: Botswana, 23 km on MaunShorob road, Yalala 425 (holotype P; isotype K).

DISTRIBUtION. Africa: Botswana, Namibia, South Africa (KwaZulu-Natal, Limpopo, North West and Northern Cape), Tanzania, Uganda, Zambia \& Zimbabwe. SE U.S.A. to Mexico. South America: Argentina \& Paraguay.

SPECIMENS EXAMINED. BOTSWANA. Toromoja, Botletle R., 22 April 1975, J. F. Ngoni 424 (K!); S of Toromoja School on bank of Botletle R., 22 April 1971, G. Pope 360 (K!); Northern Division, Toten, 18 March 1965, H. Wild E R. B. Drummond 7146 (K!); Selinda Spillway $23 \mathrm{~km} \mathrm{~S}$ of the Tsetse Fly Control Road, $18^{\circ} 44.779^{\prime} \mathrm{S}, 23^{\circ} 06.260 ' \mathrm{E}$, alt. $969 \mathrm{~m}, 25$ Nov. 2004, Alison $\mathcal{E}$ Roger Heath 703 (K!); $\pm 1 \mathrm{~km} \mathrm{~W}$ of Chief's Camp, Chief's Island, Okavango Delta, 19²18.371'S, $22^{\circ} 54.221^{\prime} \mathrm{E}$, alt. 960 m, 3 Sept. 2009, Alison E Roger Heath $1700(\mathrm{~K}$ !); within $8 \mathrm{~km} \mathrm{~S}$ of Motswiri Camp, $18^{\circ} 46.529^{\prime} \mathrm{S}, 2^{\circ} 02.399 ' \mathrm{E}, 27$ Nov. 2004, Alison $\mathcal{E}^{\circ}$ Roger
Heath 722 (K!); $\pm 2 \mathrm{~km}$ SW of Chief's Camp, Chief's Island, Okavango Delta, $19^{\circ} 18.583 ' \mathrm{~S}, 2^{\circ} 54.171$ 'E, alt. 975 m, 12 Nov. 2011, Alison Ẽ Roger Heath 2166 (K!). MOZAMBIQUE. Magaia, 18 Jan. 1898, s. coll.12054 (K!). TANZANIA. 6 km NW of Dar es Salaam, Bagamoyo road, just beyond Village Museum, on left, 31 July 1971, R. Wingfield 1744 (K!); Mchungu Forest, Utete Distr., Coast Region $7^{\circ} 40^{\prime} \mathrm{S}$, 39¹7'E, 27 Aug. 1990, FrontierTanzania Coastal Forest Research Programme 1391 (K!); Dar es Salaam, 3 June 1966, R. W. Haines 4146 (K!); Dar es Salam, 3 Sept. 1926, A. Peter 44876 (K!). UGANDA. Mengo Distr., Kirindi, Dec. 1935, Chandler 1480 (K!). ZAMBIA. Sesheke Distr., NE corner of Sioma Ngwezi National Park, 9 Aug. 2006, M. G. Bingham $\mathcal{E}$ M. A. Vestergaard 13096 (K!).

HABITAT. River banks \& margins and edges of wetlands; alt. $900-1100 \mathrm{~m}$.

CONSERVATION STATUS. Least Concern (LG) due to its extent of distribution.

NOTES. This subspecies differs from the typical subspecies in its markedly rugose nutlet (Fig. 1D). As 


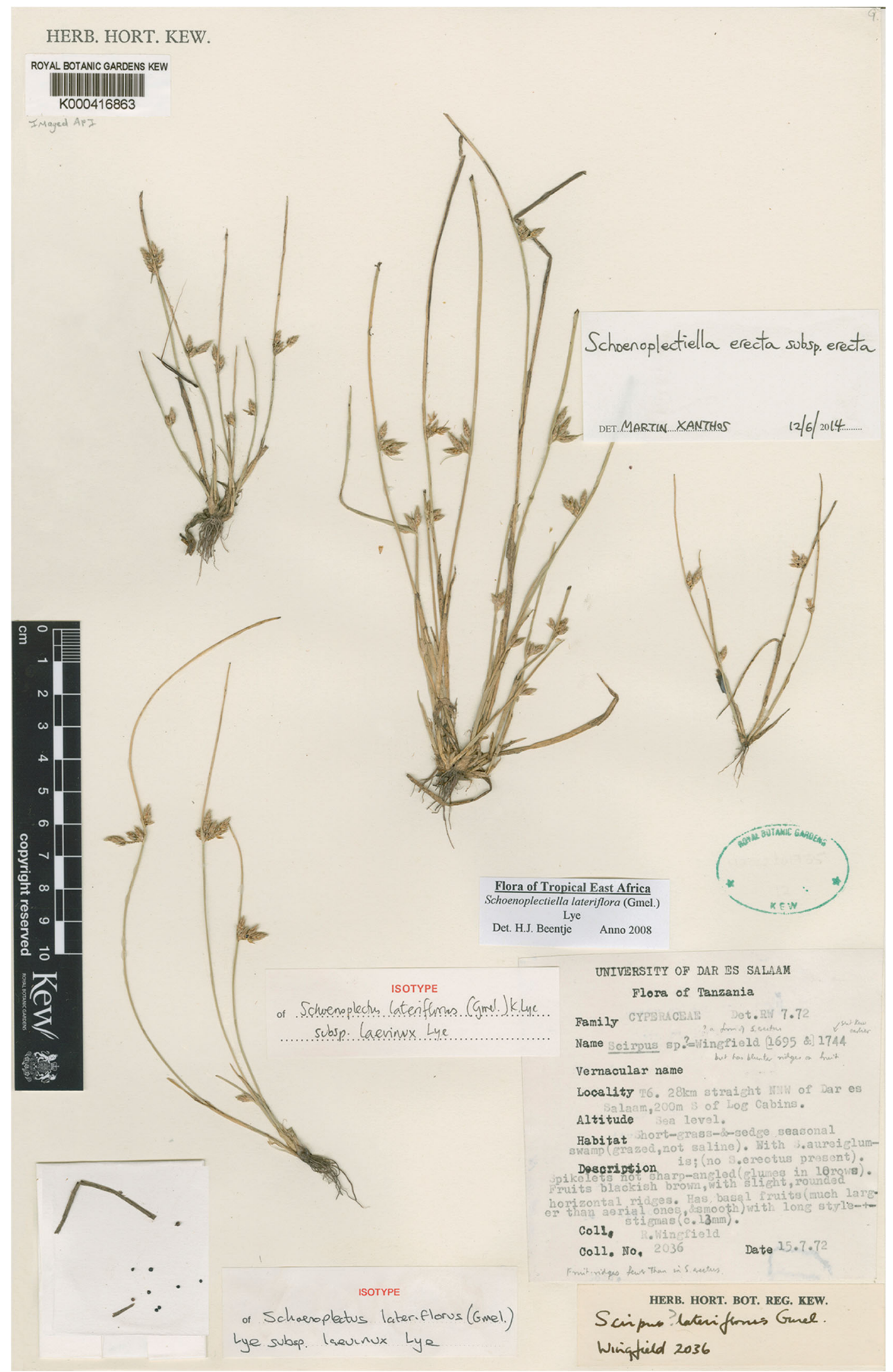

Fig. 2. Isotype of Schoenoplectiella lateriflora subsp. laevinux Lye. 
explained in the notes above, some intergradation in this character may occur between the two subspecies.

Schoenoplectiella lateriflora (J. F. Gmel.) Lye (2003: 25); Beentje (2010: 35). Type: Sri Lanka, König s.n. (holotype LD).

Annual, tufted. Culms, few to many closely packed, 5 - $50 \mathrm{~cm}$ long (including overtopping erect, inflorescence bract), $0.4-1.8 \mathrm{~mm}$ wide, ridged, triangular to almost terete. Leaves sheaths $1-2 \mathrm{~cm}$ long, often lowest enclosing basal female floret, style 3branched, 15 - $20 \mathrm{~mm}$ long, basal nutlet wrinkled, $2-2.5 \times 1.4-2 \mathrm{~mm}$, blades absent or if present up to $30 \mathrm{~cm}$ long, flat or folded. Inflorescence consisting of clusters of spikelets, appearing pseudolateral, overtopped by inflorescence bract, shorter than culm. Spikelets $1-20$, sessile or shortly pedunculate, $4-10 \times 2-2.5 \mathrm{~mm}$, ovoid, acute. Glumes $2-3 \mathrm{~mm}$ long, ovate to broadly boat-shaped, pale brown with reddish streaks, green midrib, mucronate, margin ciliate apically. Perianth absent. Stamens 3. Style 3branched. Aerial nutlet, broadly ovoid, trigonous or weakly so, turning black at maturity, $1.1-1.4 \times 0.8$ - $1.3 \mathrm{~mm}$, surface markedly rugose.

DISTRIBUTION. Throughout the Old World Tropics. Africa: Angola, Botswana, Central African Republic, Equatorial Guinea, Ethiopia, Ghana, Kenya, Mali, Malawi, Mozambique, Namibia, Nigeria, Senegal, Somalia, Tanzania \& Uganda. Eastern Asia to Indo-China, Malay Islands, Philippines \& Northern Australia.

SPECIMENS EXAMINED. BOTSWANA. Unnamed pan alongside Khurunxaraga/Xigera Road at 19 46.7'S, 2305.7'E, 23 Jan. 1977, P. A. Smith 1894 (K!). GHANA. Busunu; Damongo to Yapei, 10 Sept. 1965, J. B. Hall 880 (K!); just beyond Leotonou on E side Dahomey, 25 March 1952, J. K. Morton 6676 (K!). MALI. Sotuba, 10 Feb. 1960, J. E A. Raynal 5489 (K!); Dogo, Old Farm Land, 2 May 1952, J. T. Davey 111 (K!). NIGERIA. Lagos; in muddy marsh, Ikoyi Plains, 18 Nov. 1917, J. M. Dalziel 1307 (K!). SENEGAL. Mbao, Jan. 1951, Berhaut 1327 (K!); Kaide, 3 Dec. 1898, A. Chevalier 2447 (K!). TANZANIA. Mikumi National Park, $81 / 2 \mathrm{~km}$ WSW of main gate, alt. 530 m, 28 Jun. 1977, R. Wingfield 3957 (K!); Tanga Distr., Kange, 14 Aug. 1958, H. G. Faulkner 2176B (K!). MozambiQUE. Gaza, cidade de Xai-Xai.
Pequena lagoa no centro da cidade, 7 Oct. 1978, Jan de Koning 7261 (K!). ZAMBIA. Kabulamwanda, $75 \mathrm{~m} \mathrm{~N}$ of Choma, alt. 3300 ft, 21 April 1955, E. A. Robinson 1248 (K!); Kasama Distr., 96 km E of Kasama, 6 May 1962, E. A. Robinson 5153 (K!). ZIMBABWE. P.E. Dam, Salisbury, 4800 ft, 19 Oct. 1956, E. A. Robinson 1814 (K!); Nuanetsi Distr., Malangwe R., South West Matake hills, 7 May 1958, R. B. Drummond 5678 (K!).

HABITAT. Water holes, swamps, lake \& lagoon margins; alt. 0 - $1300 \mathrm{~m}$.

CONSERVATION STATUS. Least Concern (LG) due to its extensive distribution.

NOTES. The species is usually distinguished from both subspecies of Schoenoplectiella erecta by a combination of three style branches and a trigonous nutlet. The surface of the nutlet is otherwise the same as that of S. erecta subsp. raynalii.

\section{Acknowledgements}

The authors thank Tom Gregory (K) for assistance in using the scanning electron microscope.

Open Access This article is distributed under the terms of the Creative Commons Attribution 4.0 International License (http://creativecommons.org/ licenses/by/4.0/), which permits unrestricted use, distribution, and reproduction in any medium, provided you give appropriate credit to the original author(s) and the source, provide a link to the Creative Commons license, and indicate if changes were made.

\section{References}

Beentje, H. J. (2010). Cyperaceae. Flora of Tropical East Africa. Royal Botanic Gardens, Kew.

Hooper, S. S. (1972). Flora of West Tropical Africa $2^{\text {nd }}$ ed.. Millbank, London.

Lye, A. L. (1983). Studies in African Cyperaceae 27. Miscellaneous new taxa and combinations. Nordic J. Bot. 3: 241 - 244.

(2003). Schoenoplectiella Lye, gen. nov. (Cyperaceae). Lidia 6: 20 - 29.

Raynal, J. (1976). Notes Cypérologiques: 26. Le genre Schoeonoplectus II. L' amphicarpe et la sect. Supini. Adansonia ser. 2 16: 119 - 155. 